\title{
Gender-sensitive observations in public spaces as a teaching tool
}

\section{Joos Droogleever Fortuijn, Amsterdam}

\section{Introduction: the «fieldwork debate» in geography}

Doing fieldwork is seen as an essential element in teaching geography. In recent volumes of the Journal of Geography in Higher Education, for instance, fieldwork is an often-recurring theme. The following citation illustrates the importance of field work:

«Internationally, fieldwork is generally seen as intrinsic to the very nature of geographical education» (Fuller et al. 2003: 89).

Other key words supporting field work are «essential» and «most effective» (KenT et al. 1997), «distinctiveness» (PAWson \& Teather 2002), «vital», «fundamental» and «an unbelievable academic and personal experience» (RoBson 2002), «hallmark» (McGuINEsS \& Simm 2005), «central feature» (HaLl et al. 2004), while the British Quality Assessment Agency states that without fieldwork «it is impossible for students to develop a satisfactory understanding» (cited in HALL et al. 2004: 256). Fieldwork is seen as an important means to provide students with

«first-hand experience of the real world across cultures and continents, skills development and social benefits» (FulLer et al. 2006: 89).

The emphasis on fieldwork is closely connected with the development of geography in the $19^{\text {th }}$ century with colonialism and imperialism being important driving forces in the creation of academic geography (DE PATer \& VAN Der Wusten 1996; KNIPPENBerg 2002). Geographers were primarily explorers who went on expeditions in unknown areas in order to make maps and to collect facts and figures about exotic areas and people. Geographers were supposed to be white, ablebodied, tough, adventurous men, eager to suffer hardships (HaLl et al. 2004). In short, a geographer has to go and see with his own eyes.

Critique has been directed, in particular by feminist geographers, at this image of heroism and exoticism, the exclusionary practices and processes involved and the prevalence of «sight» over «cite» (observations in the field over theory in books) (Monk 2000; NAIRN 2005; Rose 1993). In particular, the heroism aspect of fieldwork is said to have led to the exclusion of the fieldwork subject, the students who do not reflect the heroic image: females, gays, disabled students, minority students, older students or students who are not fit and tough (Hall et al. 2004). The exotization aspect on the other hand, has led to the exclusion or «othering» of the fieldwork object: the places and people being looked at. According to NAIRN (2005: 293),

«the real world is never transparent and unmediated. Fieldtrips trade on a <logocentric essentializing epistemology»».

Or in the words of Monk (2000: 170) referring to NAIRN:

«[fieldwork] may reinforce negative stereotypes and feelings of fear, insecurity, or privilege.»

Fieldwork tends to reinforce thinking in binary categories, in «we» and «them», instead of contesting this way of thinking.

Nevertheless, fieldwork and gender-sensitive observations are part of the teaching repertoire in feminist geography, as exemplified in feminist geography textbooks (Domosh \& Seager 2001; Rose 1993; Women and Geography Study Group 1997). These teaching practices and experiences do not refer to residential fieldwork in distant destinations (the situations in which the exclusionary processes are most pronounced), but are related to ordinary public spaces in known and nearby cities, where «the commonplace may be rendered exotic» (Pawson \& Teather 2002: 277). In these practices, students are encouraged to do fieldwork in a critical and reflective way and to analyze the daily behaviour of ordinary people in nonexotic contexts. These practices are characteristic for a «feminist» pedagogy in which students' personal experiences are used as learning resources. According to WebBer (2006), using personal experiences

«transform [students] from passive recipients of knowledge to active knowers who see themselves as agents of social change» (WEBBER 2006: 455).

Feminist geographers draw the attention of students to the very nature of public spaces as «public» spaces, referring to the public-private dichotomy (Domosh \& SEAGER 2001; McDowell 1999) and the peculiarities of that dichotomy, the processes of appropriation, inclusion and exclusion, and the way public spaces form an expression of the gendered nature of our societies and constitute unequal gender relations (LofLAND 1973; Rose 1993). Public spaces can be seen as arenas where gendered social roles, relations and identities are (re)produced, represented and contested.

These fieldwork exercises are meant to enhance the understanding of students on gendered behaviour, (power) relations, identities, feelings of belonging and how this is expressed, shaped and reinforced by the design, formal regulation, presentation and marketing and informal appropriation of public spaces. 


\begin{tabular}{|l|c|c|}
\hline & Sample & Response \\
\hline Number of persons & \pm 50 & $1938 \%$ \\
\hline Number of University Departments & 27 & $1556 \%$ \\
\hline Number of countries & 20 & $1155 \%$ \\
\hline
\end{tabular}

Tab. 1: Response case study «Observations in Public Spaces as a Teaching Tool», 2007 Rücklauf zur Fallstudie «Beobachtungen in öffentlichen Räumen als Lehrmethode», 2007 Réponse à l'étude de cas «Observations de l'espace public comme outil d'enseignement», 2007

This article reports on a small case study on teaching practices and experiences of feminist geographers from different countries using gender-sensitive observations in teaching. After a general outline of the case study, the article turns to the presentation of the similarities and differences in teaching practices. This is followed by a brief evaluation of the teaching experiences by the respondents. In the last section, the teaching practices and experiences are discussed in connection with differences in academic cultures between countries and between academic disciplines.

\section{Case study facts and figures}

In May 2007, an e-mail questionnaire was sent to all participants of the IGU Commission on Gender and Geography Symposium on «Sustainable Public Spaces» at the University of Zurich, Switzerland. The following questions were posed:

1. Do you let students make observations in public (urban) spaces, such as shopping malls, parks, railway stations, streets and squares, as part of a geography course (or did you in the past)? Which course? For first, second, third or fourth year students? Is gender one or the main dimension of these observations?

2. Could you give a short description of the assignment on observations in public spaces? What are students supposed to do and how?

3. What is your experience with this type of in-field observation as a teaching instrument? How does it make students gender-sensitive?

Of the close to 50 academic experts on feminism and sustainable public spaces contacted, 19 persons (38 percent) answered the questionnaire. They represented 15 different university departments and one national academy of sciences from eleven countries: nine European countries, the United States and Israel (see Table 1).
The majority of the respondents (13) had experiences with the type of assignment in question and sent details about 17 assignments applied in eleven different university departments in nine different countries. The majority of the assignments were developed in geography departments; however, one originated from an urban anthropology department and one from an urban planning department at a technical university. Seven respondents sent one or more examples of assignments in the original language (English, Catalan, Dutch and German - the last three were translated into English by the author), while one Greek respondent sent an assignment example in translation.

With a few exceptions, the assignments were for advanced bachelor or master students. Seven assignments were part of a gender course, nine were part of another course but with gender as a main focus and one did not refer to gender aspects. Not all courses were geography courses: many were interdisciplinary. In some cases, the observations were implemented after theory, in other cases theory followed observations. The qualitative analysis of the approaches discussed herein refers to both the assignment examples as well as the questionnaire answers.

\section{A common outline}

All of the assignments appeared to follow, in more or less detail, the structure: go, see, (feel) and report (see Box 1):

- select a public space in your city (park, square, playground, pedestrian street, public transport, railway station, welcome area of an airport, pub, restaurant, shopping mall, department store, shop with sports equipment, sports event or industrial zone),

- observe what is going on for a period of time at different times of the day and different days of the week,

- look at specific gendered aspects (see below), 
«Students have to go to particular public spaces (e.g. public square, preferably a square in a neighbourhood, part of a park, pedestrian street, pub or café) on particular days and times for a period of time; as a first step they have to count how many men and women use the place; then they have to observe how different bodies operate in space: whether they sit or pass alone or in company (what company), how exactly they move across space, how they sit on a bench or a café chair, which particular positions they choose (e.g. near a wall, with their back «protected» so to speak, in the middle of action), how they perform (e.g. whether they make noise or not, whether they speak loud or not, with gestures) [...] Students are allowed to chat briefly with people and ask questions about their presence in the particular public space.»

Box 1: Description of an assignment, Technical University of Athens, Greece Beschreibung einer Übungsaufgabe, Technische Universität Athen, Griechenland Description d'un devoir, Université Technique d'Athènes, Grèce

- in some cases: chat or interview people or listen to what they are talking about,

- take notes (in some cases support analysis with audiotapes, videotapes, photos, map drawing, making sketches),

- report, reflect, and discuss (written report, oral presentation with visual materials, theatre, discussion).

Students were invited to specifically observe the following aspects:

- design and lay-out (forms, colours, materials, lightning),

- regulation (formal and informal access rules, rules of behaviour, presence of security staff, cameras),

- presentation and marketing (including advertising materials),

- presence/absence of people with different characteristics (gender, age, sexual orientation, race/ethnicity, class, ability, religion),

- use of space (activity, mobility, routings, groupings),

- relations/interactions (between visitors, between staff and visitors, between staff of different status),

- bodily exposure and performance (clothing, make up, hair-style, gestures, noise, occupation of space),

- feelings of comfort and belonging (as expressed non-verbally or in conversations),

- positionality (relation observer - observed).

\section{Different approaches}

Despite this common structure, remarkable differences could be found as well. Two examples of (parts) of assignments, both developed for a Feminist Geography course for fourth year students, one from the geography department of the University of Zurich (Box 2) and one from the geography department of the University of California Los Angeles (Box 3), illustrate the diversity in teaching approaches. In general, two differ- ent styles can be distinguished. The first style (typical for the examples from the geography and planning department of the University of Amsterdam, the Technical University of Athens, the geography department of the University of Bern, the geography and planning department of the California State University Chico, the geography and human environment department of the Tel Aviv University, the geography and regional science department of the University of Vienna, and the geography department of the University of Zurich) is a semi formal style with specified, protocolized instructions for students, such as the formulation of hypotheses, designing a research protocol, doing proof observations, working with a prescribed observation format and coding. In this type of assignment, students are required to apply a combination of quantitative techniques (counting, detailed mapping, structured interviews, and data coding) as well as qualitative techniques (narratives, photos, videos, chats, and open interviews). Students write full reports or give oral presentations, with an emphasis on detailed documentation, and are required to reflect on the methodology. In short, this style focuses on the observed object.

The second style, characteristic for the examples from the geography department of the University of Durham, the geography department of the University of California Los Angeles and the anthropology department of the Free University of Brussels (the example from the geography department of the Autonomous University of Barcelona has characteristics of both styles), is more informal, open and qualitative, with an emphasis on self-reflection and the positionality of the observer. Students report in short reflective written notes, in oral presentations with narratives, pictures, sketches and theatre or in group discussions. In short, this style focuses on the subjectivity of the observer. The first approach pays attention to the impact of the observer on the observation setting, while the second approach is concerned with the meaning of the obser- 


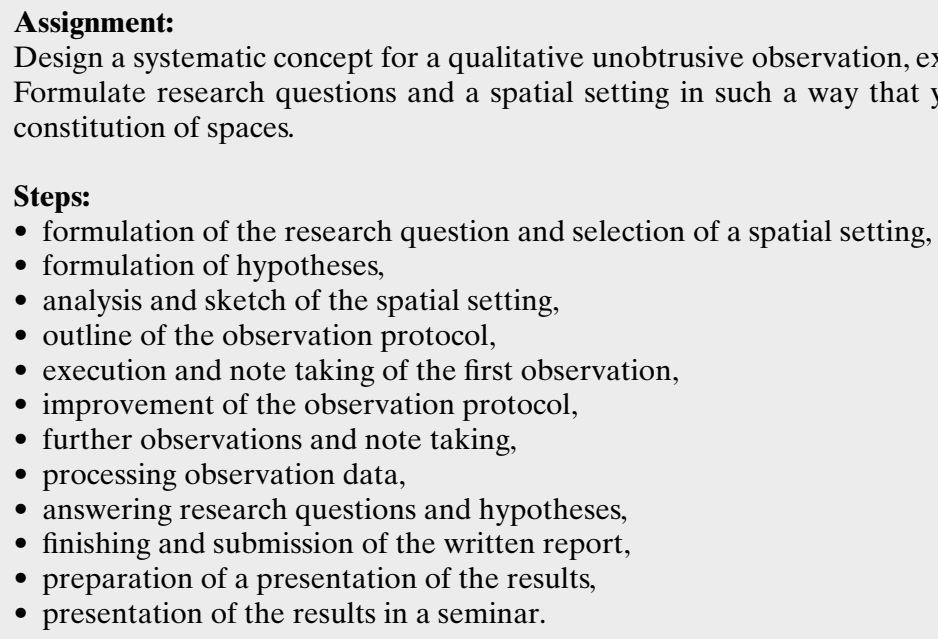

- formulation of the research question and selection of a spatial setting,

- formulation of hypotheses,

- analysis and sketch of the spatial setting,

- outline of the observation protocol,

- execution and note taking of the first observation,

- improvement of the observation protocol,

- further observations and note taking,

- processing observation data,

- answering research questions and hypotheses,

- finishing and submission of the written report,

- preparation of a presentation of the results,

- presentation of the results in a seminar.

Box 2: Assignment in the course «Gender and Space», University of Zurich

Übungsaufgabe im Kurs "Geschlecht und Raum», Universität Zürich

Devoir du cours «Genre et Espace», Université de Zurich

vation setting for the student-observer. The following formulations are typical of the latter approach (italics inserted by the author): «Select a safe public space, i.e. not a pub west of the river» (from an assignment of the University of Durham), and «Spend some time in a place you are ethno racially, gender, age conspicuous» (from an assignment of the University of California Los Angeles) or, in contrast,

«[... a small research in which you apply a gender analysis of a geographic aspect of your own daily environment» (originally in Catalan, translation by the author) (from an assignment of the Autonomous University of Barcelona).

The latter example was commented by the respondent as follows: «[students] like to work in known environments, they feel <experts on those places, they move freely and confidently there.»

The main characteristics of the two approaches are summarized in Box 4. The main distinction is between a semi-formal and an informal style. None of the examples can be seen as completely formal; an emphasis on open questions, qualitative methodology, facts and feelings, informal reporting and reflection is characteristic for feminist teaching in all assignments in this analysis.

\section{Evaluation of observations as a teaching tool}

All assignments reported were seen as effective teaching tools. There was no scepticism in the responses. «It really helps», «It is always successful», «We highly recommend», «Extremely effective», «They learn a lot!», «My experience is very good» are typical comments. The observations are seen as effective because they relate to what students learn and how they learn. The following quotations demonstrate that these exercises help students to understanding theoretical notions:

«A good introduction to gender differences; we can then start talking about theoretical issues» (Technical University of Athens).

«It made gender differences more concrete» (University of Tel Aviv).

«The students discovered the answers to some of their theoretical dilemmas» (University of California Los Angeles).

«The assignment gave our students the opportunity to apply and experience the theoretical concepts on gender and space, discussed beforehand» (University of Zurich).

The observations stimulate students to become aware of gender differences:

«I think it really helps to open their eyes and minds» (Autonomous University of Barcelona).

«By purposefully observing the dynamics of use of public space the students discover the gender dimension themselves» (University of Bern).

«They became aware of their own previous beliefs on the neutrality of space and their stereotypes about gendered behaviour. They got to know the difficulties of carrying out an observation that does not unreflectively reaffirm gendered stereotypes» (University of Zurich). 
Observation assignment:

«[...] unequal social relations are both expressed and constituted through spatial differentiation» (Rose 1993: 113).

We have been discussing the history of the idea of «public» and «private» spaces and debating whether as feminists the dichotomy can be put to work for us or whether the binary reinforces existing hierarchies of power.

Consider the quote by GiLlian Rose above and think of a public site where you have been acutely aware of inequality. Visit that site for an hour or two and observe what is going on there. Upon what does the inequality appear to be based (e.g. class, race, ethnicity, gender, sexualities, physical appearance)? How do you personally feel in this space? How are others regarding you? Notice the spatial arrangements that affect how different people are occupying the space you are in. Jot down some notes while you are there, if you can, and sketch the layout of the area you are observing, noting who is where, doing and saying what.

Later, write up the observation experience including your feelings and reflections upon who was doing what in the space, why you noticed the unequal relations between people there, and how the space was used differently by different parties present. What drew you to choose this space? How does your own physical presence there affect others there, if at all? Reflect upon how others might understand your presence there based upon assumptions they might make if you were noticed.

Box 3: Assignment in the course «Feminist Geography», University of California Los Angeles

Übungsaufgabe im Kurs «Feminist Geography», Universität California Los Angeles

Devoir du cours «Géographie féministe», Université de Californie à Los Angeles

According to a few respondents, these exercises are in particular effective for students who were not aware of gender differences before:

«Many of the Geography major students were not sensitive to gender or sexual difference. They were in the class out of convenience, and some of the students, especially the males, were not convinced that there is gender inequality or that gender matters. This exercise was most useful for those students» (University of California Los Angeles).

The diversity of the group of students in terms of gender, age, class, race/ethnicity, sexual orientation and place of origin can be used effectively:

«The collective resources of student groups at work (their diversity in terms of age, class, gender, and in general abilities to perform social situations) can also be used to design expected in-field observations and interactions» (Free University of Brussels).

«I think that the idea of letting them choose the place increases motivation and brings into the classroom a great diversity of places, not only in the sense of kinds of places, but also from different areas as our students come from very distant and different places. This allows us to enrich discussions with comparisons» (Autonomous University of Barcelona).

Respondents working with a semi-formal teaching style seem to focus more on the theoretical and methodological effectiveness, while the informal style emphasizes the effectiveness in terms of awareness and diversity.
The following quotations demonstrate the effectiveness in terms of how students learn: students seem to be more motivated by this type of work than by standard classroom work:

«Students seemed to have enjoyed doing the assignment, to have been highly committed and to have learned a lot» (University of Zurich).

«Students seem to like fieldwork and interactive learning» (California State University Chico).

«They come to next sessions with more questions, more ideas to discuss based on their personal experiences» (Autonomous University of Barcelona).

\section{Discussion}

This small case study on practices and experiences with observations in public space as an instrument in feminist geography teaching draws attention to differences in teaching styles and academic cultures. Feminist geographers make their students gender-sensitive in two different ways: either by means of protocolized observations, detailed documentation and reflections on observation methods or by means of informal and open observations with an emphasis on self-reflection and positionality. This variation in teaching styles might be seen as a difference between an Anglo-American academic culture (informal, open, relational) and a continental European culture (formal, protocolized, object-oriented) (Droogleever FortuiJn 2002; Nel 1999; SHEPHERD et al 2000). However, the non-gender 


\begin{tabular}{|l|l|}
\hline Semi-formal & Informal \\
Specified, protocolized & Open \\
Quantitative and qualitative & Qualitative \\
Emphasis on detailed documentation & Emphasis on self-reflection \\
Object-oriented & Subject-oriented (relational) \\
\hline
\end{tabular}

Box 4: Two teaching styles

Zwei Lehrmethoden

Deux méthodes d'apprentissage

examples from the California State University Chico and the urban anthropological example from the Free University of Brussels, suggest another interpretation: the difference between geography embedded in a social science academic environment and geography in a planning and architecture related environment, characteristic for the examples from the University of Amsterdam, Technical University of Athens, Tel Aviv University, University of Vienna and California State University Chico. This is in line with BradbeER's (1999) analysis of barriers to interdisciplinarity and the ambivalent position of geography within the universe of academic disciplines. Following KolB's cycle of experiential learning, BRADBEER distinguishes four different learning styles according to a concrete-abstract and an active-reflective dimension. Physics, chemistry and mathematics are seen as examples of disciplines with an abstract-reflective learning style, engineering as an example of an abstract-active discipline, law as an example of a concrete-active discipline and history, modern languages and sociology as examples of concrete-reflective disciplines. BRADBEER sees geography, biology and environmental sciences as transitional and remarks (ibid.: 387)

«that disciplinary differences also have a national variability and that there is, so to speak, a geography of geography.»

According to BRADBEER, geography develops in some countries in conjunction with physical sciences (abstract-reflective), in some countries in conjunction with planning and architecture (concrete-active) and in other countries in conjunction with sociology and anthropology (concrete-reflective). In fact, what is seen here is not only national variability, but noticeable differences between university departments and persons within departments as well.

The teaching styles of the feminist geographers in this case study also have certain aspects in common. In particular, the discussed field work assignments focus on known, commonplace and nearby public spaces (as opposed to distant and exotic destinations) and encourage students to critically observe these places from a gender perspective. In this way, the respondents in this case study agree that it is possible to avoid the dangers of stereotyping and exotization and to make students gender-sensitive. Future research is necessary to assess how effective the various teaching approaches are in the development of gender awareness of different groups of geography students. This future research should not be restricted to the perspective of teachers but should include the students' voices as well.

\section{References}

BRADBEER, J. (1999): Barriers to interdisciplinarity: disciplinary discourses and student learning. - In: Journal of Geography in Higher Education 23: 381-396.

De Pater, B. \& H. Van der Wusten (1996): Het geografische huis: opbouw van een wetenschap. - Muiderberg: Coutinho.

Domosh, M. \& J. Seager (2001): Putting women in place. Feminist geographers make sense of the world. - New York: The Guilford Press.

DroogleEver FortuiJn, J. (2002): Internationalising learning and teaching: a European experience. - In: Journal of Geography in Higher Education 26: 263273.

Fuller, I., GASkin, S. \& I. ScotT (2003): Student perceptions of Geography and Environmental Science fieldwork in the light of restricted access to the field, caused by foot and mouth disease in the UK in 2001. - In: Journal of Geography in Higher Education 27: 79-102.

Fuller, I., Edmonson, S., France, D., Higgitt, D. \& I. RATINEN (2006): International perspectives on the effectiveness of Geography fieldwork for learning. - In: Journal of Geography in Higher Education 30: 89-102. 
Hall, T., Healy, M. \& M. Harrison (2004): Fieldwork and disabled students: discourses of exclusion and inclusion. - In: Journal of Geography in Higher Education 28: 255-280.

Kent, M., Gilbertson, D. \& C. Hunt (1997): Fieldwork in Geography teaching: a critical review of the literature and approaches. - In: Journal of Geography in Higher Education 21:313-332.

KNIPPENBERG, H. (2002): Het begin: Cornelius Marius Kan en zijn opvolgers. - In: KNIPPEnberG, H. \& M. VAN Schendelen (eds): Alles heeft zijn plaats. 125 jaar Geografie en Planologie aan de Universiteit van Amsterdam 1877-2002. - Amsterdam: Aksant: 1-22.

LofLAND, L.H. (1973): A world of strangers. Order and action in urban public space. - Prospect Heights, Ill.: Waveland Press.

McDowell, L. (1999): Gender, identity and place. Understanding Feminist Geographies. - Oxford: Blackwell.

McGuiness, M. \& D. Simm (2005): Going global? Longhaul fieldwork in undergraduate Geography. - In: Journal of Geography in Higher Education 29:241-255.

MonK, J. (2000): Looking out, looking in: the «other» in the Journal of Geography in Higher Education. - In: Journal of Geography in Higher Education 24: 163-178.

NAIRN, K. (2005): The problems of utilizing «direct experience» in Geography education. - In: Journal of Geography in Higher Education 29: 293-310.

NeL, E. (1999): The Geography discipline network guides to good teaching, learning and assessment practice: a Southern African perspective. - In: Journal of Geography in Higher Education 23: 252-257.

Pawson, E. \& E.K. Teather (2002): «Geographical expeditions»: assessing the benefits of a studentdriven fieldwork method. - In: Journal of Geography in Higher Education 26: 275-290.

Robson, E. (2002): «An unbelievable academic and personal experience»: issues around teaching undergraduate field courses in Africa. - In: Journal of Geography in Higher Education 26: 327-344.

Rose, G. (1993): Feminism and Geography. The limits of geographical knowledge. - Minneapolis: The University of Minnesota Press.

Sheppard, I.D.H., Monk, J.J. \& J. Droogleever ForTUIJN (2000): Internationalising Geography in higher education: towards a conceptual framework. - In: Journal of Geography in Higher Education 24: 285-198.

WeBbER, M. (2006): Transgressive pedagogies? Exploring the difficult realities of enacting feminist pedagogies in undergraduate classrooms in a Canadian University. - In: Studies in Higher Education 31: 453-467. Women and Geography Study Group (1997): Feminist Geographies. Explorations in diversity and difference. - Women and Geography Study Group of the Royal Geographical Society and the Institute of British Geographers, Harlow: Longman.

\section{Abstract: Gender-sensitive observations in public spaces as a teaching tool}

Public spaces can be seen as arenas where gendered social roles, relations and identities are (re)produced, represented and contested. Because of their (assumed) public character - crowded, open, accessible and visible - these spaces are extremely useful as «observatories» for teaching and learning geography. This article presents and discusses 17 examples of assignments of eleven different universities in Europe, the United States and Israel in which students are encouraged to observe public spaces in order to understand the gendered use of space, interactions in space and the physical and symbolic design of public spaces, and to reflect on their observations from a gender perspective. Two different teaching styles are distinguished:semi-formal (detailed, protocolized and object-oriented) and informal (open, relational and subject-oriented). These differences in teaching styles are argued to reflect differences in academic cultures between countries and between disciplinary paradigms.

Keywords: fieldwork, teaching styles, gender, public spaces, observations

\section{Zusammenfassung: Geschlechts-bewusste Beobachtun- gen in öffentlichen Räumen als didaktisches Instrument} Öffentliche Räume können als Arenen verstanden werden, in denen geschlechtsbezogene soziale Rollen, Beziehungen und Identititäten dargestellt, (re)produziert und angefochten werden. Aufgrund ihres (vermeintlich) öffentlichen Charakters - belebt, offen, zugänglich und überschaubar - sind diese Orte ausgesprochen nützliche «Observatorien» im und für den Geographieunterricht. Dieser Artikel präsentiert und diskutiert 17 Beispiele von Lehrmodulen an elf verschiedenen Universitäten in Europa, den Vereinigten Staten und Israel. In allen Modulen wurden die Studierenden dazu angeregt, Beobachtungen in öffentlichen Räumen durchzuführen. Ziel war es, das Verständnis für die geschlechtsgeprägten Nutzungen von und Interaktionen in öffentlichen Räumen sowie den geschlechtsdifferenzierenden Symbolgehalt des materiellen Raumdesigns zu fördern. Diese Beobachtungen waren zudem unter einer Geschlechtsperspektive kritisch zu reflektieren. In der inhaltlichen Auswertung der Module kristallisierten sich zwei unterschiedliche didaktische Auftragsstile heraus: ein semi-formaler Stil (detailliert, protokollbezogen und objektorientiert) und ein informaler Stil (offen, relational, subjektorientiert). Diese unterschiedlichen Lehrstile können auf spezifische akademische Kulturen in den verschiedenen Ländern und disziplinäre Paradigmen zurückgeführt werden.

Schlüsselwörter: Feldarbeit, Lehrmethoden, Gender, öffentliche Räume, Beobachtungen 
Résumé: Observer les différences de genre dans les espaces publics: un outil pour l'enseignement

Les espaces publics peuvent être vus comme des arènes dans lesquelles les rôles sociaux, les relations et les identités sont (re)produites, représentées et contestées. A cause de leur caractère public (supposé), qui se rapporte au fait qu'il s'agit d'espace vivants, ouverts, accessibles et visibles, ces espaces sont extrêmement utiles en tant qu'observatoires pour enseigner et apprendre la géographie. Cet article présente et discute 17 exemples de devoirs provenant de 11 universités différentes en Europe, aux Etats-Unis et en Israël, dans lesquels les étudiants sont encouragés à observer les espaces publics pour comprendre l'usage de l'espace selon le genre, les interactions dans l'espace et la conception physique et symbolique des espaces publics, et pour réfléchir à leurs observations d'un point de vue des études de genre. Deux styles d'enseignements différents sont distingués: le style semi-formel (détaillé, avec un protocole et orienté vers un objet) et le style informel (ouvert, relationnel et orienté vers un sujet). Ces différences dans les styles d'enseignements reflètent des différences de cultures académiques entre les pays et entre les paradigmes disciplinaires.

Mots-clés: travail de terrain, méthodes d'enseignement, genre, espaces publics, observations

Dr. Joos Droogleever Fortuijn, Department of Geography, Planning and International Development Studies, University of Amsterdam, Nieuwe Prinsengracht 130, 1018 VZ Amsterdam, The Netherlands. e-mail: j.c.droogleeverfortuijn@uva.nl

\section{Manuskripteingang/received/manuscrit entré le} 8.6.2008

Annahme zum Druck/accepted for publication/accepté pour l'impression: 3.3.2009 